Original Article

Artigo Original

Aparecido José Couto Soares ${ }^{1}$ Maria Silvia Cárnio ${ }^{1}$ Haydée Fiszbein Wertzner ${ }^{1}$

Keywords

Reading

Evaluation

Learning

Educational Status

Language

Descritores

Leitura

Avaliação

Aprendizagem

Escolaridade

Linguagem

Correspondence address:

Aparecido José Couto Soares

Rua Cipotânea, 51, Cidade Universitária, São Paulo (SP), Brasil, CEP: 05360-160.

E-mail: ajcsoares@usp.br

\section{Profile of reading accuracy acquisition \\ of students from elementary school}

\author{
Perfil de aquisição da acurácia de leitura \\ de crianças do ensino fundamental
}

\begin{abstract}
Purpose: To characterize the profile of reading accuracy acquisition of children from the elementary school, considering word extension and syllabic structure. Methods: This study counted on 29 children from the third grade and 28 from the fourth grade of the Brazilian elementary school, with mean age of 8:5 and 9:3 years, respectively, who did not present learning disorders. All participants underwent oral reading assessment through texts according to each school level. The texts were analyzed considering the range of word length and syllabic structure. The performance of the students was analyzed according to the accuracy percentage concerning word length and syllabic structure. All data underwent statistical analysis. Results: We noticed that the variability in the percentage increased due to the number of syllables, with more incidences of error in students from the third year. Furthermore, data pointed out greater accuracy of students from the fourth year with regard to word length and syllabic structure. Analysis of variance with repeated measures indicated interaction effect between both groups and the studied variables. Conclusion: This study showed evidence that word length is a strong factor to reading accuracy acquisition in Brazilian Portuguese. In addition, words with syllabic structure different from the pattern commonly seen in the Portuguese language are more difficult to be read by children of lower schooling levels.
\end{abstract}

\section{RESUMO}

Objetivo: Caracterizar o perfil de acurácia de leitura de crianças do ensino fundamental, considerando a extensão e a estrutura silábica das palavras. Métodos: Participaram deste estudo 29 crianças do terceiro ano e 28 do quarto ano do ensino fundamental, com média de idade de 8:5 e 9:3, respectivamente e que não apresentassem alterações de leitura e escrita. Todos os sujeitos realizaram a leitura oral de textos adequados para sua faixa escolar, que foram caracterizados quanto à frequência das diferentes extensões de palavras e estrutura silábica. Analisou-se o desempenho dos sujeitos na leitura conforme a porcentagem de acertos em função da extensão da palavra e da estrutura silábica. Os dados foram submetidos à análise estatística. Resultados: Verificou-se que a variabilidade das porcentagens de acertos aumentou em função da extensão das palavras, com maior incidência de erros nos escolares do terceiro ano. Observou-se também melhor acurácia de leitura dos estudantes do quarto ano em relação à extensão da palavra e à estrutura silábica. A análise de variância com medidas repetidas apontou efeito de interação entre ambos os grupos e as variáveis estudadas. Conclusão: $O$ presente estudo mostrou evidências de que a extensão da palavra é um fator determinante para a aquisição da acurácia de leitura no Português Brasileiro. Os dados indicaram ainda que a leitura de palavras com estrutura silábica diferente do padrão mais comum da língua portuguesa é mais difícil de ser realizada por crianças com menos tempo de escolarização.

Study carried out at the Speech Language Pathology and Audiology Course of the School of Medicine, Universidade de São Paulo - FMUSP - São Paulo (SP), Brazil.

(1) Speech Language Pathology and Audiology and Occupational Therapy Department of the School of Medicine, Universidade de São Paulo - FMUSP - São Paulo (SP), Brazil.

Conflict of interests: nothing to declare. 


\section{INTRODUCTION}

Reading is a complex ability consisting of multiple interdependent processes and it involves the integration of different linguistic-cognitive abilities ${ }^{(1-3)}$. This is an important skill that sets the development trajectory of the individual because it enables them to widen their knowledge of the world and vocabulary, once that, in nowadays society, great part of the information is acquired through reading, whether that is on the Internet or through apps on different electronic devices.

In Brazil, one of the countries with the highest rate of poor reading performance, according to what was registered in the last evaluation by the Programme for International Student Assessment (PISA) ${ }^{(4)}$, deeper investigation on the parameters of fluent reading is extremely important to provide subsidies so that this reality is changed in medium and long terms. Among the most-often studied parameters of fluent reading is accuracy, and several studies have shown its importance and contribution in the building of strategies for the development of fluent reading ${ }^{(5-7)}$.

Within the last years, many international studies ${ }^{(8-10)}$ have emphasized the importance of evaluating the development of reading accuracy for the monitoring of children's evolution, as well as the effectiveness of reading intervention programs. However, a matter still under discussion in the literature concerns the way of evaluating reading accuracy, as well as the analysis criteria that should be considered. For Brazilian Portuguese (BP), there are some proposals on evaluation and analysis criteria of reading accuracy that consider the amount of words read correctly and the amount of words read correctly per minute ${ }^{(5,11,12)}$. In these proposals ${ }^{(5,11,12)}$, the analysis criteria are based on orthographic coding rules ${ }^{(13)}$.

Despite having promoted advances in the understanding of the difficulties presented by children in reading accuracy, the analysis through coding rules is detailed and specific, which can make its use difficult for education professionals. Therefore, analyzing the reading considering the extension of the words and their syllabic structure may have brought contributions for a better characterization of the pattern of acquisition and development of accurate reading.

Another advantage of this kind of analysis is to provide more consistent subsidies for the intervention on reading problems and to lead to actions that can reduce the poor rates commonly presented by Brazilian readers in international reading evaluations $\mathrm{s}^{(5,11,12,14,15)}$.

Thus, the objective of this study was to characterize the reading accuracy profile of children in elementary school, considering the extension and syllabic structure of the words.

\section{METHODS}

The research was approved by the Ethics Committee of the institution under no. 149/11. The participants of this study were 29 children of the third year (GP1) and 28 from the fourth year (GP2) of elementary school of a public school in the western district zone of São Paulo, totaling 57 subjects. The average age in GP1 was 8:5 and in GP2 9:3 years.

To participate in the study, the following inclusion criteria were considered: absence of related complaints or indicators of hearing and/or vision alterations and indicators of neurological, behavioral, or cognitive disorders, as well as alterations in speech language; difficulties or disorders of reading learning and absence of retention in school permanent records; performance within the expected for the age in the Test of Child Language Evaluation $\mathrm{ABFW}^{(16)}$; and performance classified as average or superior for the school education level in the total score of the School Performance Test (SPT) ${ }^{(17)}$.

\section{Procedures for the selection of subjects}

After the authorization by the managers of the public school, the parents were sent an informed consent for authorizing their children to participate in the study.

The parents who signed the informed consent were sent a questionnaire regarding the development of speech and written language of their children, according to that used in a recent study $^{(15)}$. In addition to that, the teachers were required to fill out an informative questionnaire on the academic performance and the behavioral characteristics of each child included in the sample $^{(15)}$. Only children whose parents and/or legal guardians did not have any kind of complaints in the questionnaires participated in the following stage of selection of subjects. In the cases where language and/or speech alterations were detected, the parents were oriented and referred to speech language and audiology therapy closer to their households.

Next, the children selected were submitted to speech language and audiology evaluation as for the phonological aspects of the oral language and the evaluation of the written language. Regarding the investigation of phonological aspects, the test of imitation was applied in the phonology area of the test of child language in phonology, vocabulary, fluency, and the ABFW's pragmatic areas ${ }^{(16)}$. In relation to the evaluation of written language, the SPT was used, according to the descriptions in the manual for its use and interpretation ${ }^{(17)}$. The test consists of three subtests: written, reading, and arithmetics. The use of SPT lasts approximately 20 to 30 minutes with each child, providing a general result on academic performance for each one of them.

\section{Use of the reading test and accuracy analysis}

To characterize reading accuracy, a text was selected for GP1 and another one for GP2, according to the school year of the subjects, considering that both texts belong to the Reading Comprehension Instruction for Expository Text ${ }^{(18)}$. The children were asked to read the text out loud and in the way they were used to doing. The readings were recorded by the evaluator and transcribed for further analysis.

It is important to highlight that many authors stated that the texts used for obtaining the parameters of reading fluency must be in accordance to the school education level of the individuals, their sociocultural level, and their literacy practice ${ }^{(3,19-21)}$. Taken these factor into consideration, we chose to use different texts, respecting the profile of readers of different schooling levels.

To better analyze reading accuracy, two evaluation texts were characterized both as for the number of monosyllables, disyllables, trisyllables, and polysyllables, and in relation to the frequency of syllabic 
structure types. Thus, it was possible to observe a greater number of words of all extensions in the GP2 text, with higher amount of trisyllables and polysyllables and higher concentration of words with more complex syllabic structure (e.g., CCV), as shown in Table 1.

For analysis purposes, it was considered as the correct reading of the target stimuli that respected grapho-phonemic relations and the orthographic rules. It was also verified that the performance of subjects in reading according to the percent correct was in relation to the extension of the word (monosyllable, disyllable, trisyllable, polysyllable) and their syllabic structure (V, VV, VC, CV, CVV, CCV, CVC).

\section{Statistical method}

After collection and tabulation, the data were submitted to statistical analysis. To compare reading accuracy in relation to the types of words intra- and intergroup, the test analysis of variance with repeated measures was applied. To verify the differences pointed out in the analysis of variance with repeated measures, the p-values were corrected by the Bonferroni procedure. In the tests of hypothesis, a significance level of 0.05 was established.

Table 1. Analysis of extension and syllabic structure of words in the texts

\begin{tabular}{lcc}
\hline & GP1 & GP2 \\
& $\mathrm{n}(\%)$ & $\mathrm{n}(\%)$ \\
\hline Extension of the word & & $65(38.4 \%)$ \\
Number of monosyllables & $40(43.4 \%)$ & $54(31.9 \%)$ \\
Number of disyllables & $31(33.6 \%)$ & $35(20.7 \%)$ \\
Number of trisyllables & $14(15.2 \%)$ & $11(6.5 \%)$ \\
Number of polysyllables & $5(5.4 \%)$ & $4(2.3 \%)$ \\
Number of polysyllables & $2(2.1 \%)$ & \\
(five or more syllables) & & $48(14.1 \%)$ \\
Syllabic structure & $21(12.5 \%)$ & $3(0.8 \%)$ \\
V syllables & $8(4.7 \%)$ & $21(6.1 \%)$ \\
VV syllables & $7(4.1 \%)$ & $159(46.9 \%)$ \\
VC syllables & $77(46.1 \%)$ & $28(8.2 \%)$ \\
CV syllables & $9(5.3 \%)$ & $12(3.5 \%)$ \\
CVV syllables & $14(8.3 \%)$ & $68(20 \%)$ \\
CCV syllables & $32(19.1 \%)$ & 169 \\
CVC syllables & 92 & \\
Total number of words & &
\end{tabular}

Caption: V = vowel; VC = vowel/consonant; CVV: consonant/vowel/vowel; $\mathrm{CCV}=$ consonant/consonant/vowel; CVC: consonant/vowel/consonant; $\mathrm{CV}=$ consonant/vowel

\section{RESULTS}

In this section, the results of performance of children in relation to reading accuracy as for the extension of words and syllabic structures are presented.

\section{Performance according to the extension of words}

The descriptive analysis of percent correct according to the extension of the word is shown in Table 2.

The individual profiles of reading accuracy by extension of the words are represented in Figure 1. It is noticeable that the percentage correct varies according to the amount of syllables, with greater growth in GP1.

The analysis of variance with repeated measures pointed out that there is an effect of interaction between group and word extension $(p=0.008)$. This means that the differences between the types of words depend on the group (Table 3) and that the variation between groups depends on the extension of the word (Table 4).

The comparison two by two indicated several differences between the correctness percentage according to extension in both groups. The mean of the correctness percentage in polysyllable words, with five or more syllables, is lower than that for the remaining types of words within the 2 years and, therefore, this is the kind of word in which the highest percentage of mistakes occur (Table 3).

A difference in reading accuracy was observed between groups, for all the analyzed extensions, with the exception of polysyllables, in which both groups presented great variability in answers (Table 4).

\section{Analysis considering the syllabic structure of the words}

In the comparison according to the syllabic structure of the words, the greatest differences between means and median in both groups were observed in CVV structures (e.g., 'que'), CCV (digraphs such as nho and lho), and CVC (such as com and los), as observed in Table 5. Besides that, in GP1, the mean percentage of correctness in VC (e.g., ' $a s$ ') is higher than that in CVV and CVC. In the comparison between means of $\mathrm{VC}$ and $\mathrm{CCV}$, we obtained a borderline $\mathrm{p}$-value.

Table 2. Performance of children in GP1 and GP2 in reading accuracy according to the extension of the word

\begin{tabular}{|c|c|c|c|c|}
\hline \multirow{2}{*}{ Extension of the word } & \multicolumn{2}{|c|}{ GP1 $(n=29)$} & \multicolumn{2}{|c|}{ GP2 (n=28) } \\
\hline & Mean (SD) & Median (Min-Max) & Mean (SD) & Median (Min-Max) \\
\hline Monosyllables & $95.7(5.8)$ & $97.5(80.0-100.0)$ & $98.8(1.4)$ & 98.5 (95.4-100.0) \\
\hline Disyllables & 89.9 (11.9) & $92.9(57.1-100.0)$ & $98.7(1.7)$ & $100.0(94.3-100.0)$ \\
\hline Trisyllables & $74.9(19.8)$ & $78.6(28.6-100.0)$ & $92.2(5.4)$ & $94.3(80.0-100.0)$ \\
\hline Polysyllables & $81.4(23.9)$ & $80.0(20.0-100.0)$ & $91.6(8.2)$ & $90.9(72.7-100.0)$ \\
\hline Polysyllables (5+) & $53.5(37.6)$ & $50.0(0.0-100.0)$ & $75.0(9.6)$ & $75.0(50.0-100.0)$ \\
\hline
\end{tabular}


Table 3. p-values obtained in the comparison two by two between that means of reading accuracy according to the extension of the words

\begin{tabular}{lcc}
\hline Comparison & GP1 & GP2 \\
\hline MONO x DI & $>0.999$ & $>0.999$ \\
MONO x TRI & $<0.001$ & 0.001 \\
MONO x POLY & 0.021 & $<0.001$ \\
MONO x POLY (5+) & $<0.001$ & $<0.001$ \\
DI x TRI & 0.013 & 0.001 \\
DI x POLY & 0.639 & $<0.001$ \\
DI x POLY (5+) & $<0.001$ & $<0.001$ \\
TRI x POLY & $>0.999$ & $>0.999$ \\
TRI x POLY (5+) & $<0.001$ & $<0.001$ \\
POLY x POLY (5+) & $<0.001$ & $<0.001$ \\
\hline
\end{tabular}

Caption: $\mathrm{MONO}=$ monosyllabic words; $\mathrm{DI}=$ disyllabic words; $\mathrm{TRI}=$ trisyllabic words; $\mathrm{POLY}=$ polysyllabic words; $\mathrm{POLY}(5+)=$ polysyllabic words with five or more syllables

Table 4. p-values obtained in the comparison between the means of correctness percentage between GP1 and GP2

\begin{tabular}{lc}
\hline Type & p-value \\
\hline MONO & 0.023 \\
DI & $<0.001$ \\
TRI & $<0.001$ \\
POLY & 0.093 \\
POLY (5+) & 0.013 \\
\hline
\end{tabular}

Caption: MONO = monosyllabic words; $\mathrm{DI}$ = disyllabic words; TRI = trisyllabic words; $\mathrm{POLY}=$ polysyllabic words; $\mathrm{POLY}(5+)=$ polysyllabic words with five or more syllables
In the analysis of variance with repeated measures, an interaction was observed between the syllabic structure of the words and school year $(\mathrm{p}<0.001)$. The comparison between groups also showed evidences that children in GP2 are more accurate than the ones in GP1 V, CCV, and CVC structures and a borderline p-value for the CV structure (Table 6). It is noteworthy that the results did not include the VV structure because both groups had $100 \%$ correct answers.

In the analysis mentioned earlier, however without including the results in the VV structure, an interaction was observed between the structure of the word and the schooling year $(\mathrm{p}<0.001)$. The results in Table 6 show that, in GP1, the mean percentage of correct answers in VC is higher than that in $\mathrm{CVV}$ and CVC. In the comparison between the means of VC and $\mathrm{CCV}$, a borderline p-value (between 0.05 and 0.10 ) was observed. In GP2, no difference was observed between the means of correctness percentage in the six related structures.

The comparison two by two indicated some difference between the percentages of correct answers, varying according to the syllabic structure of the words. The students in GP2 showed higher mean percentage of correctness than the ones in GP1 in V, CCV, and CVC structures. In the analysis of the percentages of correct answers in the $\mathrm{CV}$ structure, a p-value between 0.05 and 0.10 was obtained (Table 7).

\section{DISCUSSION}

The contribution of this study was to indicate that the analysis of correctness percentage according to the extension
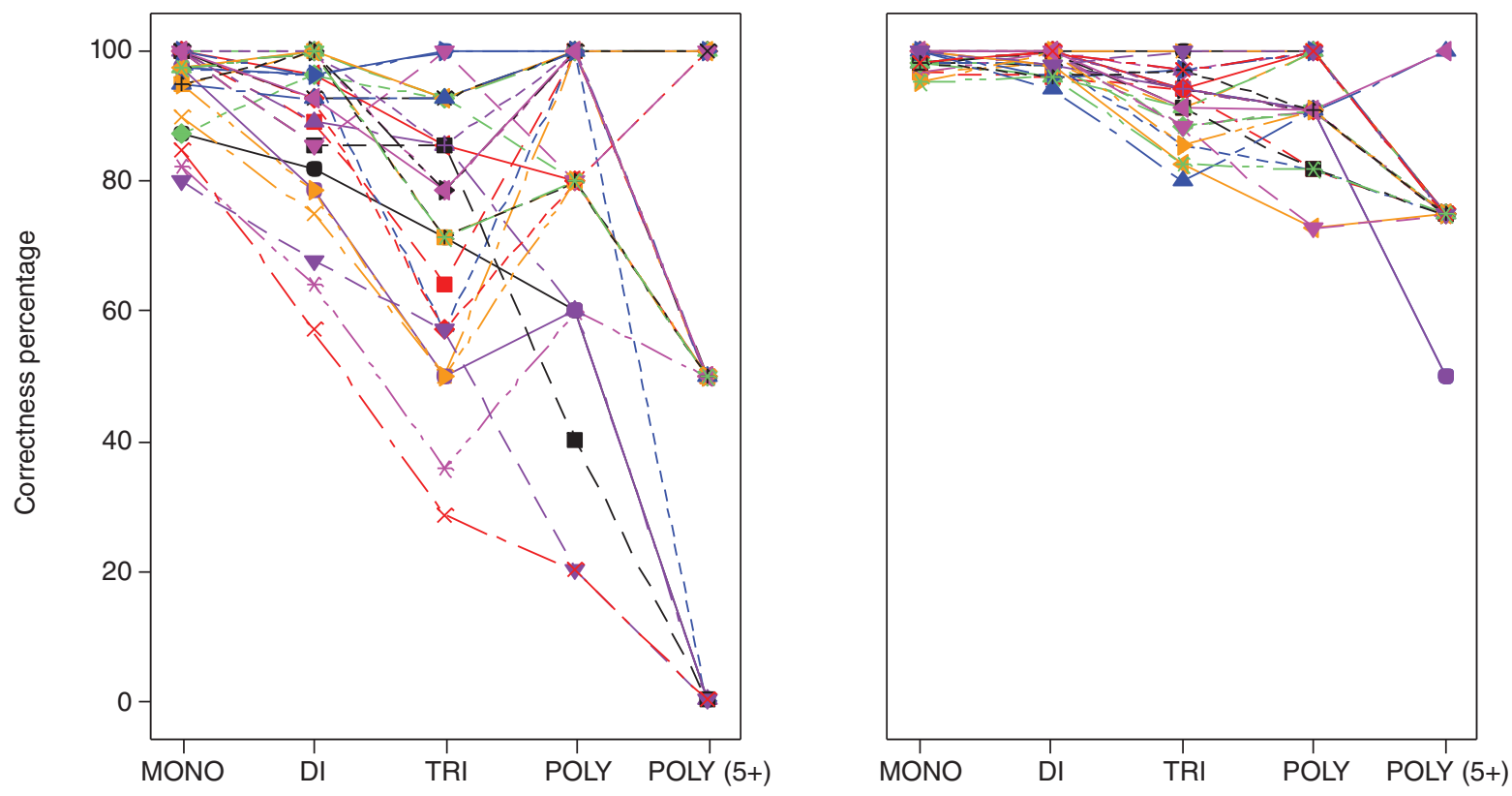

Extension of the word

Figure 1. Individual reading accuracy profile in GP1 and GP2 
Table 5. Performance of GP1 and GP2 in reading accuracy according to the syllabic structure of the words

\begin{tabular}{|c|c|c|c|c|}
\hline \multirow{2}{*}{ Syllabic structure } & \multicolumn{2}{|c|}{ GP1 $(n=29)$} & \multicolumn{2}{|c|}{ GP2 $(n=28)$} \\
\hline & Mean (SD) & Median (Min-Max) & Mean (SD) & Median (Min-Max) \\
\hline V (\%) & $93.9(8.3)$ & $100.0(69.2-100.0)$ & $98.2(2.3)$ & 97.8 (91.1-100.0) \\
\hline VC (\%) & $98.7(7.0)$ & $100.0(62.5-100.0)$ & $98.7(3.4)$ & $100.0(85.7-100.0)$ \\
\hline CVV (\%) & $91.1(18.9)$ & $100.0(28.6-100.0)$ & $98.2(3.7)$ & $100.0(85.0-100.0)$ \\
\hline $\operatorname{CCV}(\%)$ & $91.6(8.3)$ & $92.9(71.4-100.0)$ & $98.6(3.0)$ & $100.0(92.3-100.0)$ \\
\hline CVC (\%) & $90.2(13.2)$ & $93.5(48.4-100.0)$ & $99.0(1.0)$ & $98.5(97.0-100.0)$ \\
\hline CV (\%) & $94.8(7.7)$ & $97.4(66.2-100.0)$ & $98.1(1.3)$ & 98.7 (95.4-100.0) \\
\hline
\end{tabular}

Caption: V = vowel; VC = vowel/consonant; CVV: consonant/vowel/vowel; CCV = consonant/consonant/vowel; CVC: consonant/vowel/consonant; CV = consonant/vowel

Table 6. $p$-values obtained in the comparison between the means of correctness percentage in the structure of words two by two in each year

\begin{tabular}{|c|c|c|}
\hline \multirow{3}{*}{ Comparison } & \multicolumn{2}{|c|}{ Year } \\
\hline & Third & Fourth \\
\hline & $p$-value & $p$-value \\
\hline $\bar{V} \times \mathrm{VC}$ & 0.770 & $>0.999$ \\
\hline $\mathrm{V} \times \mathrm{CVV}$ & $>0.999$ & $>0.999$ \\
\hline $\mathrm{V} \times \mathrm{CCV}$ & $>0.999$ & $>0.999$ \\
\hline $\mathrm{V} \times \mathrm{CVC}$ & $>0.999$ & $>0.999$ \\
\hline $\mathrm{V} \times \mathrm{CV}$ & $>0.999$ & $>0.999$ \\
\hline $\mathrm{VC} \times \mathrm{CVV}$ & 0.036 & $>0.999$ \\
\hline $\mathrm{VC} \times \mathrm{CCV}$ & 0.066 & $>0.999$ \\
\hline $\mathrm{VC} \times \mathrm{CVC}$ & 0.010 & $>0.999$ \\
\hline $\mathrm{VC} \times \mathrm{CV}$ & $>0.999$ & $>0.999$ \\
\hline $\mathrm{CVV} \times \mathrm{CCV}$ & $>0.999$ & $>0.999$ \\
\hline CVV $\times$ CVC & $>0.999$ & $>0.999$ \\
\hline$C V V \times C V$ & $>0.999$ & $>0.999$ \\
\hline $\mathrm{CCV} \times \mathrm{CVC}$ & $>0.999$ & $>0.999$ \\
\hline $\mathrm{CCV} \times \mathrm{CV}$ & $>0.999$ & $>0.999$ \\
\hline $\mathrm{CVC} \times \mathrm{CV}$ & $>0.999$ & $>0.999$ \\
\hline
\end{tabular}

Caption: $\mathrm{V}=$ vowel; $\mathrm{VC}=$ vowel/consonant; CVV: consonant/vowel/vowel; $\mathrm{CCV}$ = consonant/consonant/vowel; CVC: consonant/vowel/consonant; $\mathrm{CV}=$ consonant $/$ vowel

Table 7. $p$-values obtained in the comparison between the means of correctness percentage in the third and fourth years in each type of word

\begin{tabular}{lc}
\hline Structure & $p$-value \\
\hline V & 0.036 \\
VC & $>0.999$ \\
CVV & 0.171 \\
CCV & $<0.001$ \\
CVC & 0.003 \\
CV & 0.081 \\
\hline
\end{tabular}

Caption: V = vowel; VC = vowel/consonant; CVV: consonant/vowel/vowel; $\mathrm{CCV}=$ consonant/consonant/vowel; CVC: consonant/vowel/consonant; $\mathrm{CV}=$ consonant/vowel

of the word and the syllabic structure may be applied to any reading test or text, whether in clinical or in educational areas. Another highlight of this investigation were the evidences obtained through comparison between GP1 and GP2, indicating that the analysis performed was effective when pointing out that children with longer schooling time had more accurate reading regarding words of greater extension, as well as in those with the most complex syllabic types (CVV, CCV, and CVC).
Specifically regarding reading accuracy according to the syllabic structure, it was verified a superior result for GP2 in all kinds of syllabic types, with the greatest differences observed in CVV (such as 'que'), CCV (the digraphs nho and lho), and CVC (e.g., 'los' and 'com') structures. In addition, word reading formed by digraphs and consonant clusters showed greater number of mistakes by children in GP1. On the basis of these results, it is evident that words with a more complex syllabic structure than the most frequent pattern in Portuguese (CV) seem to be more difficult to be read by children with less schooling time.

The data allow speculating that the subjects in GP1 are not yet acquainted with the spelling patterns of the language, performing the reading of all words in a regular way, suggesting they primarily use the phonological route for reading, which may have led to a higher number of mistakes. However students in GP2, who made fewer mistakes, seem to be more acquainted to the spelling patterns, using the stored orthographic representations more often due to the longer time of exposure to reading and writing. Thus, they tend to accurately read both regular and irregular words, as well as those of more complex syllabic structure.

The reading by phonological route, typical of beginner readers, depends on the use of the knowledge on grapheme and phoneme conversion rules so that the construction of the word may be carried on, and it is proven more effective in words with transparent graphemes and simple syllabic structure. However, reading through lexical route depends on a previously acquired word, memorized in the system of visual word recognition. The recovery of meaning and pronunciation of this word occurs through direct lexical addressing, considering the pronunciation obtained as a whole ${ }^{(3,19-22)}$.

In this sense, the data in this research show that more mature readers use two simultaneous reading routes, so that they can read words with regular or arbitrary spellings, with different extensions and syllabic structures, in a faster and more accurate way $y^{(3,21-24)}$.

As for the analysis of mistakes according to the extension of words, it was observed that the longer the word, the higher the variability of the answer in GP2, with the progressive increase of mistakes from trisyllable words. However, the students in GP1 presented great variability in all extensions of words, indicating that children with shorter schooling time tend to read less accurately. A greater statistical interaction was also observed between the mean of correctness and the extension of words in relation to their syllabic structure. Such results suggest that in 
the development of reading of the children in this sample, the extension of the word played a more important part than the syllabic structure.

Therefore, this study brings evidence of the importance of the extension of words used in different reading activities developed in speech language and audiology programs in schools, as well as in those of speech and language therapy. This is due to the observation that there is an increase in reading accuracy for words with higher number of syllables due to advanced schooling. The measure of extension and syllabic structure of words was an effective indicator of reading accuracy, considering schooling levels. Another advantage of these measures is its easy use and adaptation for monitoring the evolution of reading development.

The analyses proposed are easily understandable and may be used by different education professional, such as teachers or educational coordinators, in order to monitor the evolution in reading development. It is important to emphasize that this kind of analysis is vital because it contributes to advances in understanding the development of reading accuracy and allows a better tracing of the evolution of performance of Brazilian students in reading tasks.

In addition, the data in this research indicate the importance of managing the words that will be used both with children in early literacy process and for the intervention planning for students with reading problems. Such reflection is based on the evidence showing that the extension of words and their syllabic structure are important variables to be considered for the development of reading, whether in clinical or in educational areas.

\section{CONCLUSION}

This study showed evidence that the extension of words is a determinant factor in the acquisition of reading accuracy in BP. The data also indicated that the reading of syllables other than the CV pattern is more difficult for children with less schooling time. The higher the schooling level, the more the students tend to present higher numbers of correct responses for both of the studied variables.

Besides, this research showed the importance of choosing the words used in speech language and audiology programs in schools, intervention programs, and even literacy methods because, this way, it is possible to respect the profile of correct reading of words acquisition, as it was observed throughout this study.

*AJCS was responsible for the design of the study, the collection and analysis of data, analysis and interpretation of the results, writing and review of the manuscript; MSC contributed to the interpretation of results and the discussion and review of the manuscript; HFW was responsible for the design of the study, the analysis and interpretation of the results, writing and review of the manuscript.

\section{REFERENCES}

1. Capellini SA, Ferreira TL, Salgado CA, Ciasca SM. Desempenho de escolares bons leitores, com dislexia e com transtorno do déficit de atenção e hiperatividade em nomeação automática rápida. Rev Soc Bras Fonoaudiol. 2007;12(2):114-9.
2. Mousinho R, Correa J. Habilidades linguístico-cognitivas em leitores e não leitores. Pro Fono. 2009;21(2):113-8.

3. Petscher Y, Kim YS. The utility and accuracy of oral reading fluency score types in predicting reading comprehension. J Sch Psychol. 2011;49(1):107-29.

4. Brasil. Instituto Nacional de Estudos e Pesquisas Educacionais Anísio Teixeira. (2013) [Internet]. Programa internacional de avaliação de estudantes, resultados nacionais 2012. Brasília. [cited 2014 Oct 03]. Available from: http://download.inep.gov.br/acoes_internacionais/pisa/ resultados/2013/country_note_brazil_pisa_2012.pdf

5. Avila CR, Kida Ade S, Carvalho CA, Paolucci JF. Reading errors typology of Brazilian students considered good readers. Pro Fono. 2009;21(4):320-5.

6. Pinto JC, Navas AL. Efeitos da estimulação de leitura com ênfase na prosódia. J Soc Bras Fonoaudiol. 2011;23(1):21-6.

7. Pontes VL, Diniz NL, Martins-Reis VO. Parâmetros e estratégias de leitura e escrita utilizados por crianças de escolas pública e privada. Rev CEFAC. 2013;15(4):827-36.

8. Francis DJ, Santi KL, Barr C, Fletcher JM, Varisco A, Foorman BR. Form effects on the estimation of students' oral reading fluency using DIBELS. J School Psychol. 2008;46(3):315-42.

9. Duesbery L, Braun-Monegan J, Werblow J, Braun D. Practical issues in field based testing of oral reading fluency at upper elementary grades. Stud Educ Eval. 2012;38:121-6.

10. Roehrig AD, Petscher Y, Nettles SM, Hudson RF, Torgesen JK. Accuracy of DIBELS oral reading fluency measure for predicting third grade reading comprehension outcomes. J Sch Psychol. 2008;46(3):343-66.

11. Kida AS, Chiari BM, Àvila CR. Escala de leitura: proposta de avaliação das competências leitoras. Rev Soc Bras Fonoaudiol. 2010;15(4):546-53.

12. Kawano CE, Kida AS, Carvalho CA, Ávila CR. Parâmetros de fluência e tipo de erros na leitura de escolares com indicação de dificuldades para ler e escrever. Rev Soc Bras Fonoaudiol. 2011;16(1):9-18.

13. Scliar-Cabral L. Guia prático de alfabetização, baseado em princípios alfabéticos do Português do Brasil. São Paulo: Contexto; 2003.

14. Capovilla FC, Raphael WD. Enciclopédia da língua de sinais brasileira. Volume 8: o mundo de surdos em libras, palavras de função gramatical. São Paulo: Edusp; 2005.

15. Soares AJ, Jacinto LA, Cárnio MS. Memória operacional fonológica e consciência fonológica em escolares ao final do ciclo I do ensino fundamental. Rev Soc Bras Fonoaudiol. 2012;17(4):447-53.

16. Wertzner HF. Fonologia. In: Andrade CR, Befi-Lopes DM, Fernandes FD, Wertzner HF. ABFW - Teste de linguagem infantil nas áreas de fonologia, vocabulário, fluência e pragmática. Carapicuíba: Pró-Fono, 2004. p. 5-40.

17. Stein LM. Teste de Desempenho Escolar (TDE). São Paulo: Casa do Psicólogo; 1994.

18. Saraiva RA, Moojen SM, Munarski R. Avaliação da compreensão leitora de textos expositivos: para fonoaudiólogos e psicopedagogos. São Paulo: Casa do Psicólogo; 2009.

19. Ellis AW. Leitura, escrita e dislexia: Uma análise cognitiva. 6 ed. Porto Alegre: Artes Médicas; 1995.

20. Good RH, Simmons DC, Kame'enui EJ. The importance e decisionmaking utility of a continuum of fluency-based indicators of foundational reading skills for third-grade high-stakes outcomes. Sci Stud Read. 2001;5(3):257-88.

21. Wolf M, Bowers PG. The double-deficit hypothesis for the developmental dyslexias. J Educ Psychol. 1999;91(3):415-38.

22. Saine NL, Lerkkanen MK, Ahonen T, Tolvanen A, Lyytinen H. Predicting word-level reading fluency outcomes in three contrastive groups: Remedial e computer-assisted remedial reading intervention, e mainstream instruction. Learn Individ Differ. 2010;20(5):402-14.

23. Tsau SR. The effects of an automatic speech analysis system on enhancing EFL leaners' oral reading fluency. Procedia Soc Behav Sci. 2012;64:141-50.

24. Yesil-Dagli U. Predicting ELL students' beginning first grade English oral reading fluency from initial kindergarten vocabulary, letter naming, and phonological awareness skills. Early Child Res Q. 2011;26:15-29. 